\title{
Apatinib affect VEGF-mediated cell proliferation, migration, invasion via blocking VEGFR2/RAF/MEK/ERK and PI3K/ AKT pathways in cholangiocarcinoma cell
}

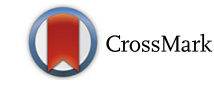

Manping Huang ${ }^{1}$, Bin Huang ${ }^{1}$, Guowen $\mathrm{Li}^{1}$ and Sainan Zeng ${ }^{2^{*}}$

\begin{abstract}
Background: Cholangiocarcinoma (CCA) is a form of cancer that easily aggress to contiguous structures. Vascular endothelial growth factor (VEGF) and VEGF receptor 2 (VEGFR2) are increased in majority species of cancers and suppress tumor progression by blocking VEGFNEGFR2. Apatinib is a highly selective VEGFR2 antagonist which has inhibitive effect on antiapoptotic and cell growth in CCA. While, the effect of apatinib cell migration and invasion in CCA is still unknown.
\end{abstract}

Methods: CCA cell lines QBC939 and TFK-1 were transfected with siKDR to establish the KDR function loss cell model, and recombined human VEGF (rhVEGF) protein was added into the culture medium to enhance the VEGF expression. RT-qPCR and western bloting were used to detect the mRNA and protein expression levels of VEGFR2 to investigate whether it was effectively repressed or activated with rhVEGF or apatinib treatment. Then, MTT, wound healing assay, and transwell matrix assay were applied to measure the effect of apatinib and rhVEGF on cell viability, migration and invasion, respectively.

Results: The mRNA and protein expressions of VEGFR2 were significantly reduced with KDR RNAi in both QBC939 and TFK-1 cells, and rhVEGF treatment increased these expression levels $(p<0.05)$. Apatinib dramatically suppressed VEGFmediated cell migration and invasion at the concentration of $100 \mathrm{nM}$ treatment and significantly decreased the expression of metastasis-associated protein such as Slug, snail and MMP9. Moreover, all of these inhibiting effects of apatinib depended on the VEGFR2 existence. In addition, VEGFR2/RAF/MEK/ERK and PI3K/AKT signal pathways were enhanced by the introduction of rhVEGF, but were dramatically suppressed after the apatinib treatment.

Conclusion: Apatinib inhibit VEGF-mediated cell migration and invasion in CCA cell lines via inhibiting the VEGFR2/ RAF/MEK/ERK and PI3K/AKT pathways. It will be a potentially effective targeted drug for CCA.

Keywords: Cholangiocarcinoma, Apatinib, VEGF, KDR (VEGFR2), RAF/MEK/ERK pathway, PI3K/AKT pathway

\section{Background}

Cholangiocarcinoma(CCA), also known as bile duct cancer, is a form of cancer that originates in the epithelial cells of bile ducts, along intrahepatic and extrahepatic biliary tree, that is defined as intrahepatic, peri-hilar and distal CCA [4, 22]. Due to the high aggressive ability, CCA

\footnotetext{
* Correspondence: zengsainan1121@163.com

${ }^{2}$ Infection Controlling Center, The Third Xiangya Hospital of Central South University, Tongzipo Road, Yuelu District, Changsha 410013, People's Republic of China

Full list of author information is available at the end of the article
}

could easily infiltrate into adjacent organs such like liver, hepatic artery and portal vein [29]. The infiltration patterns of CCA were distributed in lymph, vascular infiltration site, and lymph node metastases, which is a basic feature of CCA [6, 12].

Vascular endothelial growth factor (VEGF), originally known as vascular permeability factor (VPF), is a signal protein produced by epithelial cells [23]. It has been identified as a key player in neovascularization and cell proliferation in a variety of cancers, including the fatal biliary CCA $[5,21]$. Clinical data shows VEGF was significantly

(c) The Author(s). 2018 Open Access This article is distributed under the terms of the Creative Commons Attribution 4.0 International License (http://creativecommons.org/licenses/by/4.0/), which permits unrestricted use, distribution, and 
increased in the biopsy samples of CCA $[2,18,26]$. Furthermore, there is evidences that blocking VEGF/VEGFR2 pathway can effectively inhibit the proliferation, migration, invasion, survival and adhesion ability of hepatocellular carcinoma, hyperplastic cholangiocyte and non-small cell lung cancer [14, 32].

Apatinib, a tyrosine kinase inhibitor that selectively inhibits the vascular endothelial growth factor receptor-2 (VEGFR2, also known as KDR), could significantly inhibit intracellular VEGF signaling [28]. Benefiting from the blocking effect of VEGF pathway, apatinib play a prominent role in inhibiting tumor cells anti-apoptosis, cells proliferation in vitro and repressing the growth of xenograft tumor in vivo $[19,20]$. In additon, apatinib reveals inhibition effect on migration and invasion in KIF5B-RET driven tumors therapy [13]. However, up to now there are currently few studies on the impact of CCA migration and invasion. In this study, we investigated the role of apatinib in CCA migration and invasion via the QBC939 and TFK-1 cell line. Moreover, we also explored the potential mechanism that the inhibition effect of apatinib may via VEGFR2/RAF/MEK/ERK and PI3K/AKT pathways.

\section{Methods}

\section{Cell culture and transfection}

Human CCA cell lines QBC939 and TFK-1 were purchased from Suer Biological Inc. (Shanghai, China). QBC939 cells were cultured in Dulbecco's Modified Eagle Medium (DMEM, Sigma-Aldrich, St. Louis, MO, USA) and TFK-1 cells were cultured in RPMI-1640 medium (Gibco-BRL, Gaithersburg, MD), both supplemented with $10 \%$ heat-inactivated fetal bovine serum (Gibco; Thermo Fisher Scientific, Inc., Waltham, MA, USA), and incubated at $37{ }^{\circ} \mathrm{C}$ with $5 \% \mathrm{CO}_{2}$.

Cells were sub-cultured to 6-well plates until the confluence reached $80 \%$. The final concentration $50 \mathrm{mM}$ siKDR and siControl (labeled with a fluorescent, synthesize by Gene Pharma, Suzhou, China) were diluted in serum-free MEM, and gently mixed with Lipofectamine $2000(6 \mu \mathrm{l} /$ well, Sigma-Aldrich, St. Louis, MO, USA) following $5 \mathrm{~min}$ stand, respectively. Before added this mixture to cells, another $20 \mathrm{~min}$ stand at room temperature is needed. The transfected cells incubated at $37{ }^{\circ} \mathrm{C}$ with $5 \% \mathrm{CO}_{2}$ for $8 \mathrm{~h}$, and then change the medium into McCoy's $5 \mathrm{~A}$ medium containing $10 \%$ FBS without antibiotics. 24 h post transfection, the transfection efficiency was checked by fluorescence detection.

\section{RT-qPCR}

VEGFR2 mRNA levels from two group cells were tested by RT-qPCR. The first group cells were transfected with siKDR and siControl for $24 \mathrm{~h}$. Cells in the second group was treated with $0,20,50,100$, and $200 \mathrm{ng} / \mathrm{ml} \mathrm{recom-}$ binant human VEGF (rhVEGF, PeproTech, 100-20-2) for $2 \mathrm{~h}$. Cells were subsequently homogenized and centrifuged $\left(12,000 \mathrm{x} \mathrm{g}, 10 \mathrm{~min}, 4{ }^{\circ} \mathrm{C}\right)$ using TRIzol reagent (Sigma-Aldrich, St. Louis, MO, USA) for total RNA extraction. RNA purity and concentration were determined by Nano-Drop (Thermo Scientific).

$1 \mathrm{mg}$ total RNA was reverse transcribed into cDNA using GoScript $^{\text {tm }}$ RT system (Promega, Madison, WI, USA). qPCR was performed in triplicate as: $95{ }^{\circ} \mathrm{C}$ for $30 \mathrm{~s}, 40$ cycles of $95{ }^{\circ} \mathrm{C}$ for $5 \mathrm{~s}, 58{ }^{\circ} \mathrm{C}$ for $10 \mathrm{~s}$ and $72{ }^{\circ} \mathrm{C}$ for $30 \mathrm{~s}$, subsequently analyze melting curve. GAPDH was used as the reference gene. Primers (forward, reverse) were: VEGFR2 5'-GGAC TCTCTCTGCCTACCTCAC-3', 5'-GGCTCTTTCGCT TACTGTTCTG-3', GAPDH 5'-AGAAGGCTGGGGCT CATTTG-3', reverse 5'AGGGGCCATCCACAGTCTT C-3'. The relative fold change of VEGFR2 was calculated by $2^{-\Delta \Delta \mathrm{Ct}}$ method.

\section{MTT assay}

After QBC939 cells and TFK-1 cells were cultured to 96-well plates $\left(1 \times 10^{5}\right.$ cells/well $)$ overnight, three conditions of drug treatment were set: (1) cells treated with 0 , 10, 100, 1000 and 10,000 nM apatinib (MCE, HY13342) for $24 \mathrm{~h}$; (2) cells treated with $0,20,50,100$ and $200 \mathrm{ng} / \mathrm{ml}$ rhVEGF for $2 \mathrm{~h}$; (3) cells treated with $100 \mathrm{ng} / \mathrm{ml}$ rhVEGF for $2 \mathrm{~h}$ following treated with 10, 100, 1000 and 10,000 nM apatinib for $24 \mathrm{~h}$ And then cells were cultured for another $24 \mathrm{~h}, 10 \mathrm{mg} / \mathrm{ml}$ MTT was added and incubated for further $4 \mathrm{~h}$. After that, cells were centrifuged at $1,000 \times \mathrm{g}$ for $5 \mathrm{~min}$ at room temperature, removed supernatant, and added $100 \mu \mathrm{l}$ DMSO to each well for $30 \mathrm{~min}$ to dissolve the formazan product. The optical density (OD) was measured at $492 \mathrm{~nm}$ by a microplate reader (FLx800; BioTek, Winooski, VT, USA). The relative cell viability was normalized with control group using optical density values.

\section{Wound healing assay}

Cells were cultured to 6 -well plates $\left(2 \times 10^{5}\right.$ cells/well $)$ until about $100 \%$ confluence. $100 \mathrm{nM}$ apatinib or $100 \mathrm{ng} / \mathrm{ml}$ rhVEGF $+100 \mathrm{nM}$ apatinib were added into medium and cultured 24 h. $200 \mu \mathrm{l}$ pipette tip was used to create a wound gap on cell monolayer, and Olympus IX71 microscope (Olympus Corporation, Tokyo, Japan) at 100 times magnification was used for imaging immediately. Migration was then observed $24 \mathrm{~h}$ post wound scratched. Image-Pro Plus software (Media Cybernetics, Inc., Rockville, MD, USA) was used to calculated the relative migration distant $\%$ as: [(The relative distance recorded at $0 \mathrm{~h}$ - the relative distance recorded at $24 \mathrm{~h}$ )/the relative distance recorded at $0 \mathrm{~h}] \times 100$.

\section{Transwell matrix assay}

Control and siKDR transfected cells $\left(1 \times 10^{4}\right.$ cells/well $)$ were incubated into the top chamber of matrigel coated polyethylene terephthalate membrane $(50 \mu \mathrm{l} /$ well, Corning, 
Corning, USA), and $100 \mathrm{nM}$ apatinib or $100 \mathrm{ng} / \mathrm{ml} \mathrm{rhVEGF}$ were added into the upper chamber,. After culturing for $24 \mathrm{~h}$, cells in the upper chamber were removed gentlyand the invaded cells left at the bottom of chamber were fixed with $4 \%$ paraformaldehyde for $30 \mathrm{~min}$ and then stained with $0.1 \%$ crystal violet for $30 \mathrm{~min}$. Following by counting under an optical microscope (Olympus Corporation, Tokyo, Japan) at a magnification of 200.

\section{Western blotting}

After cells treated with/without $100 \mathrm{ng} / \mathrm{ml}$ rhVEGF, $100 \mathrm{nM}$ apatinib or $100 \mathrm{ng} / \mathrm{ml} \mathrm{rhVEGF}+100 \mathrm{nM}$ apatinib, cells were lysed using lysis buffer (Cell Signaling Technology, Danvers, USA) to extract total protein. Protein lysates were separated by $10 \%$ SDS-PAGE, followed by transfer to nitrocellulose membranes. The membrane was then blocked with $5 \%$ milk diluted in PBS at room temperature for $1 \mathrm{~h}$, followed by incubated with 1:1000 VEGFR2 antibody (ab10972, Abcam, Cambridge, MA, USA),1:5000 p-VEGFR2 (ab38473, Abcam), 1:2000 p-MEK (2338, CST), 1:1000 MEK (4694, CST), 1:2000 p-ERK1/2 (4370, CST), 1:1000 ERK (4695, CST), 1:2000 slug (ab51772, Abcam), 1:3000 Snail (ab53519, Abcam), 1:2500 MMP9 (ab38898, Abcam), 1:1500 P-AKT (ab81283, Abcam), 1:1500 AKT (ab179463, Abcam) and 1:5000 GAPDH antibody (ab8245, Abcam) overnight at $4{ }^{\circ} \mathrm{C}$ separately. Once primary antibodies were washed, membrane was incubated with goat anti-rabbit horseradish peroxidase-labeled secondary antibody (Sangon Biotech, Shanghai, China). Protein bands were detected by incubating the membrane with Western Bright enhanced chemiluminescence working solution (Advansta, Menlo Park, CA, USA). The film (Kodak XBT-1, Carestream, Xiamen, China) was scanned with Bio-rad Gel Doc XR+ (BIO-RAD, Shanghai, China).

\section{Statistical analyses}

Statistical analysis was conducted with the Social Sciences software version 17.0. Quantitative data were presented as mean \pm SD. The two-tailed Student's t test was applied to analyze statistical differences between two groups. For multiple comparisons, the one-way ANOVA was used to analyze the difference. $p<0.05$ was considered to be statistically significant. Each test data was repeated at least three times.

\section{Results}

RNA interference reduced VEGFR2 MRNA and protein levels in QBC939 and TFK-1 cells

q-PCR and western blotting were performed to investigate the mRNA and protein levels of VEGFR2 in si-KDR or si-Control transfected QBC939 and TFK-1 cells. VEGFR2 mRNA level reduced significantly, showed five and two times lower in siKDR group compared to siControl group in QBC939and TFK-1 cells, respectively ( $p<0.01$; Fig. 1a). Similarly, the protein level also reduced about 2-fold which caused by siKDR (Fig. 1b-c). Both q-PCR and western blotting results suggested KDR interference significantly reduced VEGFR2 expression in both mRNA and protein levels.

\section{VEGF activated VEGFR2 and promoted proliferation in QBC939 and TFK-1 cells}

After $2 \mathrm{~h}$ treatment of $0,20,50,100$, or $200 \mathrm{ng} / \mathrm{ml}$ rhVEGF, VEGFR2 mRNA and protein level were detected by q-PCR and western blotting. Results showedVEGFR2 mRNA level elevated along the increasing concentration of rhVEGF treatment and reached peak value at $100 \mathrm{ng} / \mathrm{ml}$, which was about 5-fold compared to control group (Fig. 2a). Moreover, VEGFR2 mRNA level kept stable when rhVEGF concentration higher than $100 \mathrm{ng} / \mathrm{ml}$ (Fig. 2a). Similarly, the intensity of VEGFR2 protein bands appeared stronger continuously accompany the increasing concentration of rhVEGF treatment and reached strongest at $100 \mathrm{ng} / \mathrm{ml}$ rhVEGF (Fig. 2b). These data showed $100 \mathrm{ng} / \mathrm{ml} \mathrm{rhVEGF}$ is the most suitable concentration for activating VEGFR2.

Following that, MTT assay was performed to show that $100 \mathrm{ng} / \mathrm{ml}$ rhVEGF had a significant greater (1.4-fold) enhancement of relative cell viability compared to control $(p<0.05$; Fig. $2 \mathrm{c})$, suggested that rhVEGF promoted cell viability in QBC939 and TFK-1 cells effectively. In addition, we analyzed the protein level of VEGFR2 by western blot, and found rhVEGF caused a significant increase of VEGFR2 while siKDR caused a significant reduction. However, $100 \mathrm{ng} / \mathrm{ml}$ rhVEGF did not significantly reverse the decrease of VEGFR2 in the KDR knockout group ( $p<0.01$; Fig. $2 \mathrm{~d})$.

Apatinib inhibites the migration and invasion of QBC939 and TFK- 1 cells

There were no changes of relative cell viability on both QBC939 and TFK-1 cells with 10 and $100 \mathrm{nM}$ apatinib treatment, but 1,000 and 10,000 nM apatinib caused a greatly reduction of relative cell viability compared to control group, suggested 1,000 nM and higher concentration of apatinib could cause cytotoxicity on CCA cells (Fig. 3a). However, we found $100 \mathrm{nM}$ apatinib was enough for CCA cell lines QBC939 and TFK-1 to cause migation and invasion inhibition $(p<0.01$; Fig. $3 \mathrm{~b}$, and $p<0.05, p<$ 0.01, respectively; Fig. 3c), Furthermore, metastatic marker Slug, snail and MMP9 protein levels in the cells treated with or without $100 \mathrm{nM}$ apatinib were detected by western blot. Result showed that apatinib could significantly inhibit the protein expression of Slug, snail and MMP9 (Fig. 3d). All these data suggested that apatinib has the effection on inhibiting cell migration and invasion of CCA. 

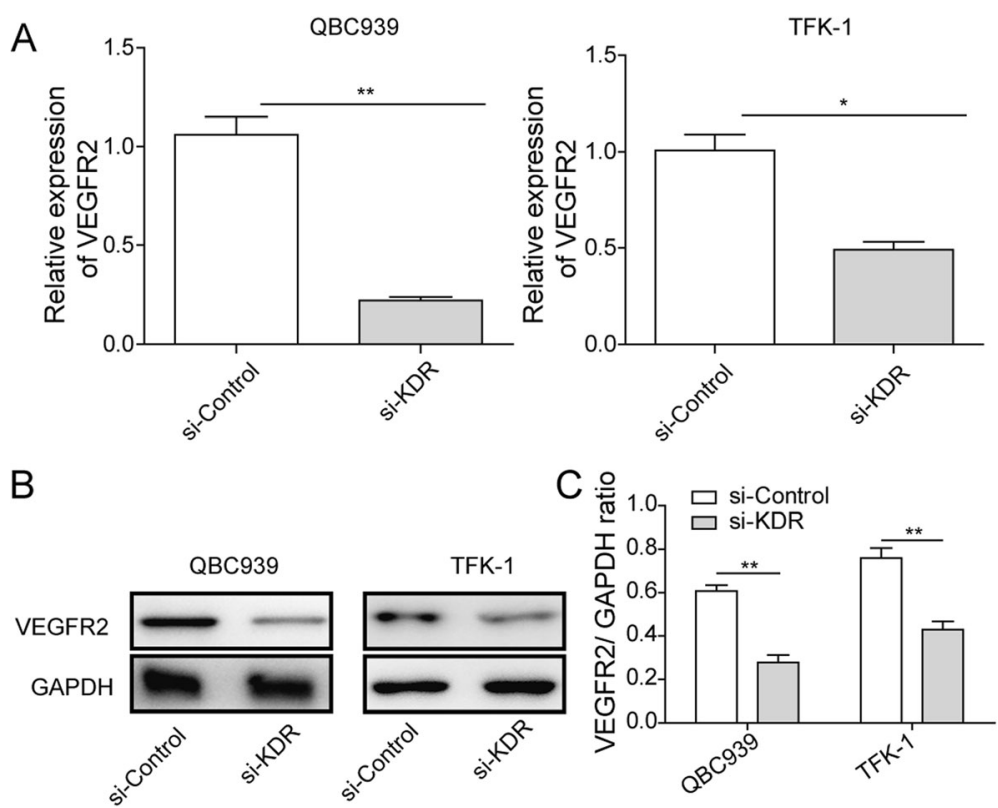

Fig. 1 VEGFR2 expression in QBC939 and TFK-1 cells transfected with siKDR or siControl. a Cells were transfected with $50 \mathrm{nM}$ siKDR or siControl for 48 h. qRT-PCR was performed to evaluate the mRNA level of VEGFR2 Data shown are means \pm SD $(n=3) .{ }^{* *} P<0.01$ and ${ }^{*} P<0.05$ in QBC939 and TFK-1 cells versus si-Control group, respectively. b Protein expression of VEGFR2 in transfected QBC939 and TFK-1 cells were also detected by western-blotting. GAPDH was detected as reference. c Densitometric analysis of the autoradiographic plaques of these proteins is shown on the Fig. 1b. Data shown are means \pm SD $(n=3) .{ }^{* *} P<0.01$ in QBC939 and TFK-1 cells versus si-Control group

\section{Apatinib played an essential role on VEGF-mediated migration and invasion in QBC939 and TFK-1 cells}

The effect of apatinib on VEGF-mediated cell viability was determined by MTT assay, that total 6 groups were set using increased concentration of apatinib from $0 \mathrm{nM}$ to $10,000 \mathrm{nM}$ with $100 \mathrm{ng} / \mathrm{ml}$ rhVEGF. $100 \mathrm{ng} / \mathrm{ml}$ rhVEGF significantly increased relative cell viability about 26\%compared to control group $(p<0.05, p<0.01$, respectively Fig. $4 \mathrm{a}, \mathrm{b}$ ). In addition to this, $10 \mathrm{nM}$ and $100 \mathrm{nM}$ apatinib reverses the viability caused by $100 \mathrm{ng} /$ $\mathrm{ml}$ VEGF to the normal rate $(p<0.05)$. But $1,000 \mathrm{nM}$ and the higher concentration showed cytotoxicity in both QBC939 and TFK-1 cells (Fig. 4a, b).

Followed that, wound healing was performed to detect the effect of apatinib (100 nM) on VEGF-mediated QBC939 and TFK-1 cell migration. On siControl group, the wound width significantly reduced $24 \mathrm{~h}$ post rhVEGF treatment), while, apatinib treatment suppressed this reduction effectively ( $p<0.001$; Fig. $4 \mathrm{c}$, d). However, on siKDR group, rhVEGF and apatinib treatment showed no significant differenceon wound width as a cause of VEGFR2 knock-down (Fig. 4c, d). These data revealed rhVEGF facilitates QBC939 and TFK-1 cell migration, and apatinib can reverse thiseffect in a VEGFR2 dependent manner.Next, transwell assays were conducted to assess the invasion ability of rhVEGF-induced cells with or without apatinib. On siControl group, rhVEGF significantly promoted the invasion of QBC939 and TFK-1 cells $(p<0.01$; Fig. $5 \mathrm{a})$, but this invasion was totally suppressed by apatinib ( $p<0.01$; Fig. 5a). However, cells in the rhVEGF and apatinib treating groups had little difference of invasion ability when KDR expression is disturbed (Fig. 5a). Protein levels of metastatic marker slug, snail, MMP9 were also detected, in siControl group, $100 \mathrm{ng} / \mathrm{ml}$ rhVEGF significantly promoted the protein expression of slug, snail and MMP9, but $100 \mathrm{nM}$ apatinib dramatically reverse this elevation effect. On the contrary, the protein levels of Slug, snail and MMP9 were stable with rhVEGF and apatinib treatment in the siKDR group (Fig. 5b). These results would reveal that effect of apatinib on AAC cell invasion relying on the presence of VEGFR2.

\section{Apatinib suppresses VEGF/VEGFR2-mediated signaling through the RAF/MEK/ERK and AKT signaling pathways} Western blotting was performed on siControl and siKDR transfection cells which treated $100 \mathrm{ng} / \mathrm{ml}$ rhVEGF with/ without $100 \mathrm{nM}$ apatinib, to determine the signaling pathway related to VEGF and its receptor VEGFR2. The expression of p-VEGFR2, VEGR2, RAF, p-MEK, MEK, p-ERK1/2, ERK1/2, p-AKT and AKT were examined, since RAF, MEK and ERK1/2 are the downstream pathway molecules of VEGFR2. Treatment with rhVEGF significantly increased the phosphorylation and total protein of VEGFR2, RAF, phosphorylated MEK, ERK1/2 and AKT protein expression level in siControl group, but had little influence on total protein level of MEK ERK1/2 and AKT 


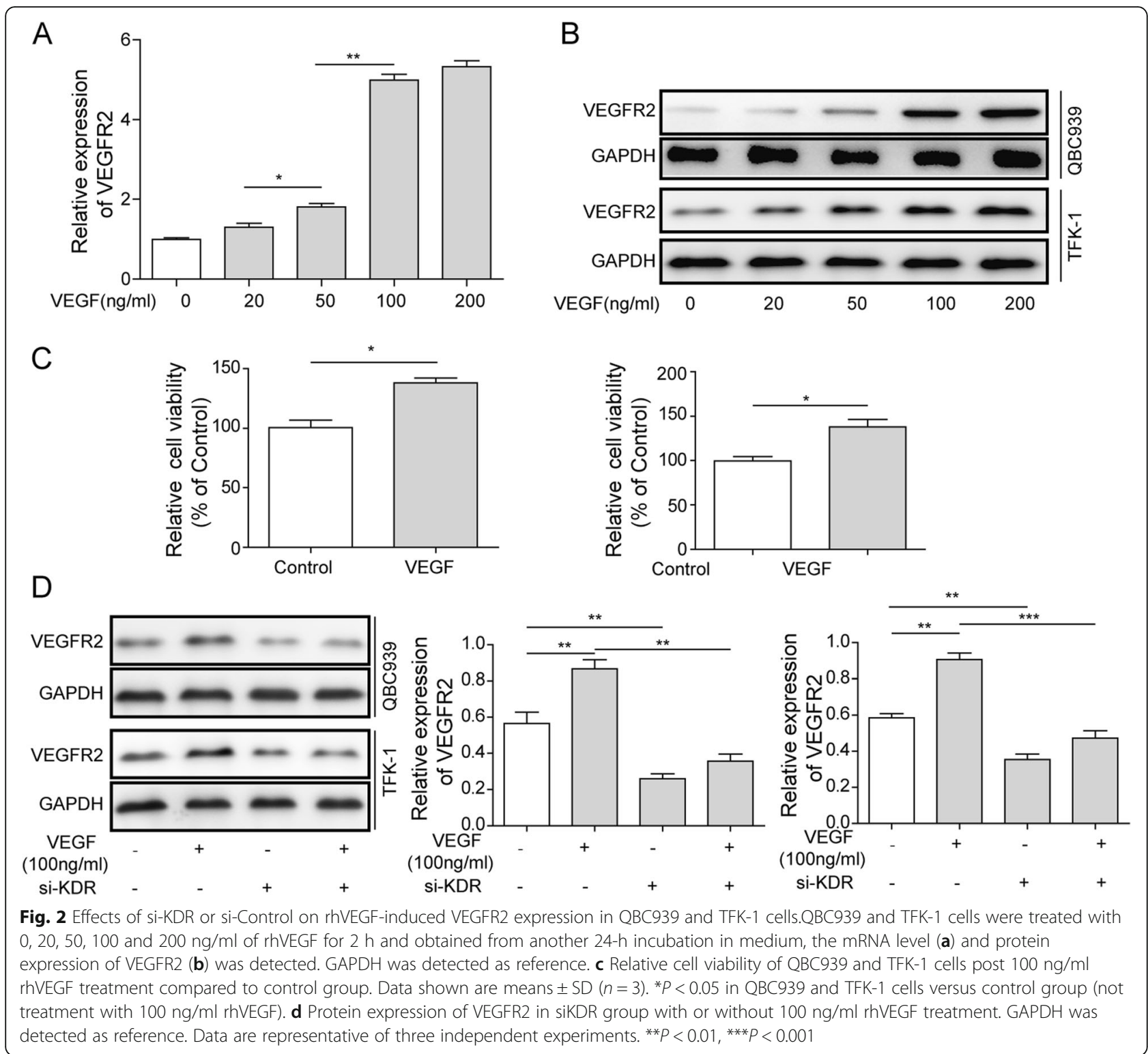

(Fig. 6a, b). After blocking VEGFR2 by apatinib, the phosphorylation and total protein level of VEGFR2, phosphorylated MEK and ERK1/2 were reverse to basal level (Fig. 6a, b). On the contrary, both rhVEGF and apatinib treatments had no influence on phosphorylation and total protein level of MEK and ERK1/2 in siKDR group (Fig. 6a, b). Phosphorylation and total protein level of VEGFR2, RAF and phosphorylated AKT were expressed very weak in siKDR group, and this weak expression were stable with or without rhVEGF and apatinib treatment (Fig. 6a, b).

\section{Discussion}

VEGF exerts its biological effects by combining and activating its receptors, which known as VEGFR2 [8, 27]. Publications reveal VEGF plays key role in CCA as the high expression level was detected in the patients' tumor tissues $[1,15]$. Hence, as the antagonist of VEGFR2, apatinib has the potential to become an effective targeted medicine of CCA $[16,19,20]$. In this study, we firstly confirmed the role of VEGF in QBC939 and TFK-1 cells, and then comfirmed the inhibition functions of apatinib in migration and invasion of these two CCA cell lines. Finally, we analyzed the potential signaling pathways Raf/MEk/ERK and PI3K/AKT that might be influenced by apatinib.

Publication reported VEGF could regulate kinds of cancer cells growth through binding to VEGFR [10]. Results in our study showed that exogenous rhVEGF activated the VEGFR2 expression and promoted the cell viability both in QBC939 and TFK-1 cells. It was consistent with publications that blocking VEGF/VEGFR2 


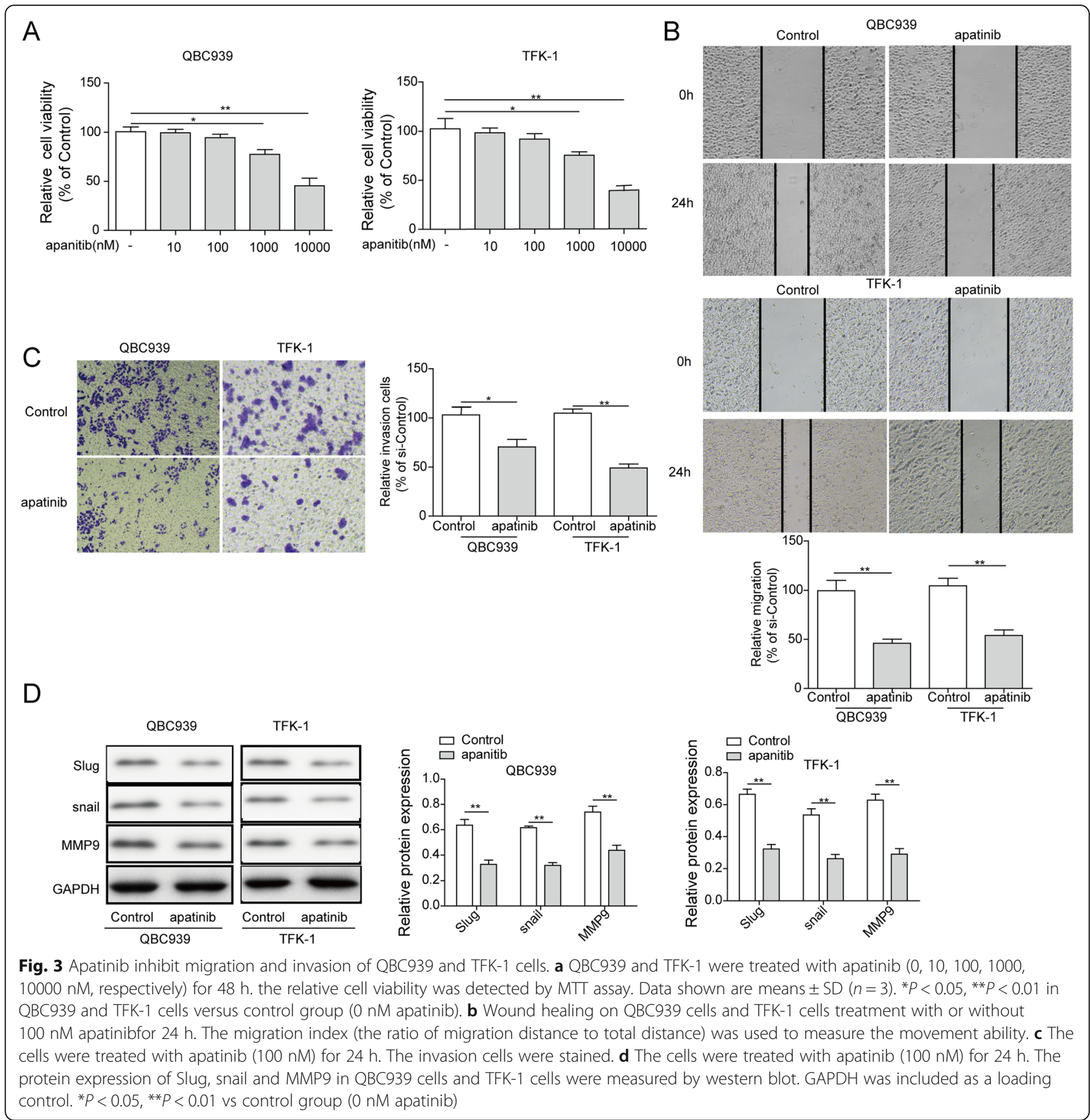

pathway have inhibition effect on the growth of cancer cells $[7,14,32]$. Moreover, one paper revealed the role of VEGF in promoting cell growth and inducing the cell apoptosis in CCA $[19,20]$. However, whether VEGF was an necessity for tumor migration or invasion in CCA remains unknown.

As the antagonist of VEGFR2, the biological functions of apatinib towards cell migration and invasion in CCA cell lines were performed in this study, and the results provide a first ever comprehensive elucidation of apatinib in anti-CCA progress. We found that it significantly inhibited cell migration and invasion. Moreover, apatinib significantly decreased the expression of metastatic marker such like Slug, snail, and MMP9 in the CCA cell lines. It was consistent with the previous research in lung adenocarcinomas, which found apatinib inhibits cellular invasion and migration by fusion kinase KIF5B-RET via suppressing RET/Src signaling pathway [13]. In addition, it was report intracellular autocrine VEGF signaling promotes EBDC cell proliferation, which can be inhibited by apatinib $[19,20]$. And we also found that exogenous rhVEGF significantly promoted migration and invasion in QBC939 and TFK-1 


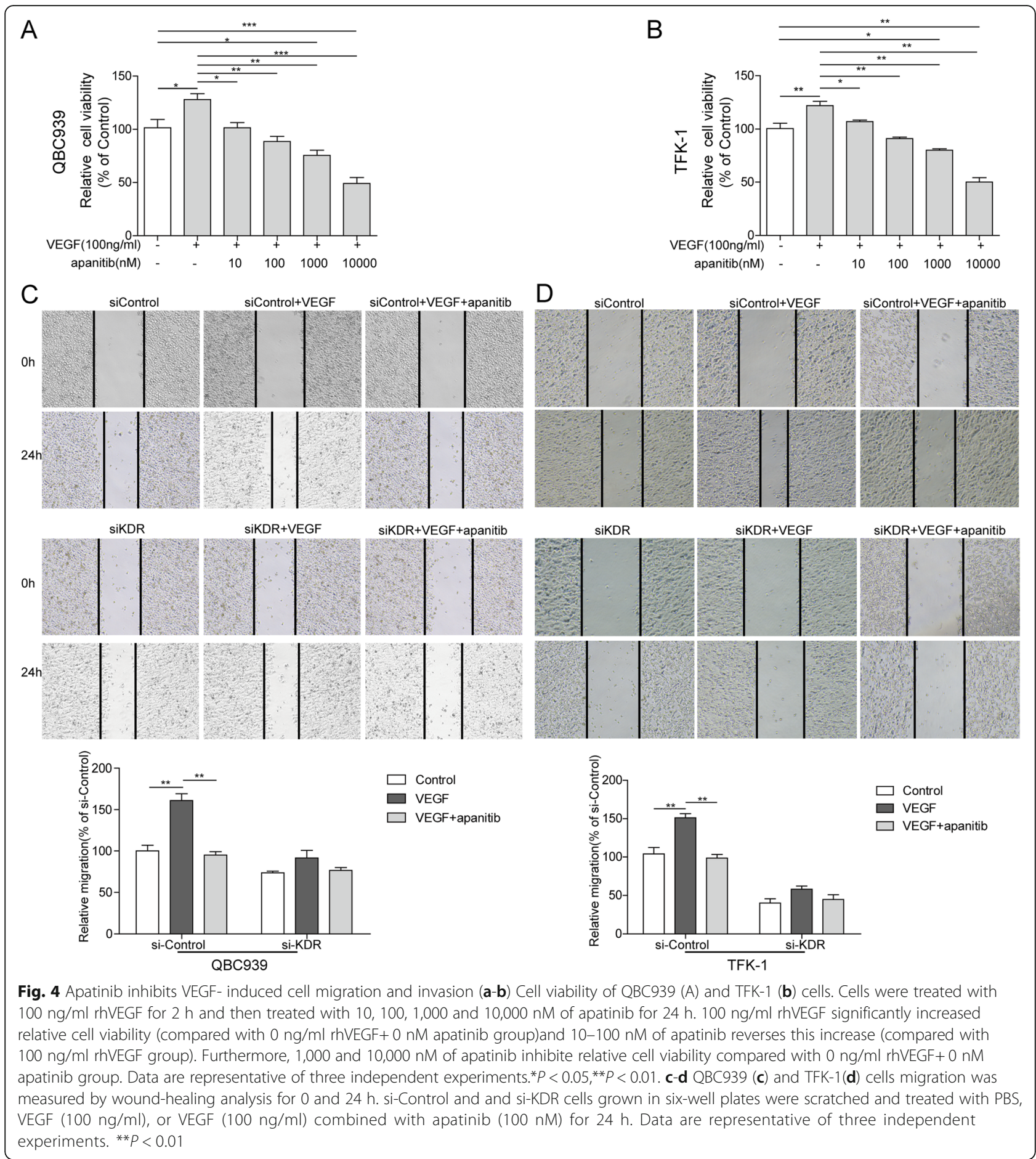

cells, whereas apatinib could reverse these effects. Combine our data and references mentioned above, it exposes the essential role of apatinib in anti-tumour effect, and the apatinib induced inhibition of cell migration and invasion in CCA.

RAF/MEK/ERK pathway has been linked in endothelial cell proliferation [17] and VEGF mediated cell survival $[3,11]$. To investigate the possible mechanism of how apatinib works on CCA cells. We found exogenous rhVEGF markedly elevated phosphorylation and total of VEGFR2 protein, and the major downstream targets: phosphorylation of RAF, MEK and ERK1/2, but did not affect the levels of total MEK and ERK1/2. On the contrary, apatinibprominently inhibited this promotion. These results disclosed apatinib could efficiently inhibit the activation of VEGFR2/RAF/MEK/ERK1/2 signal transduction 


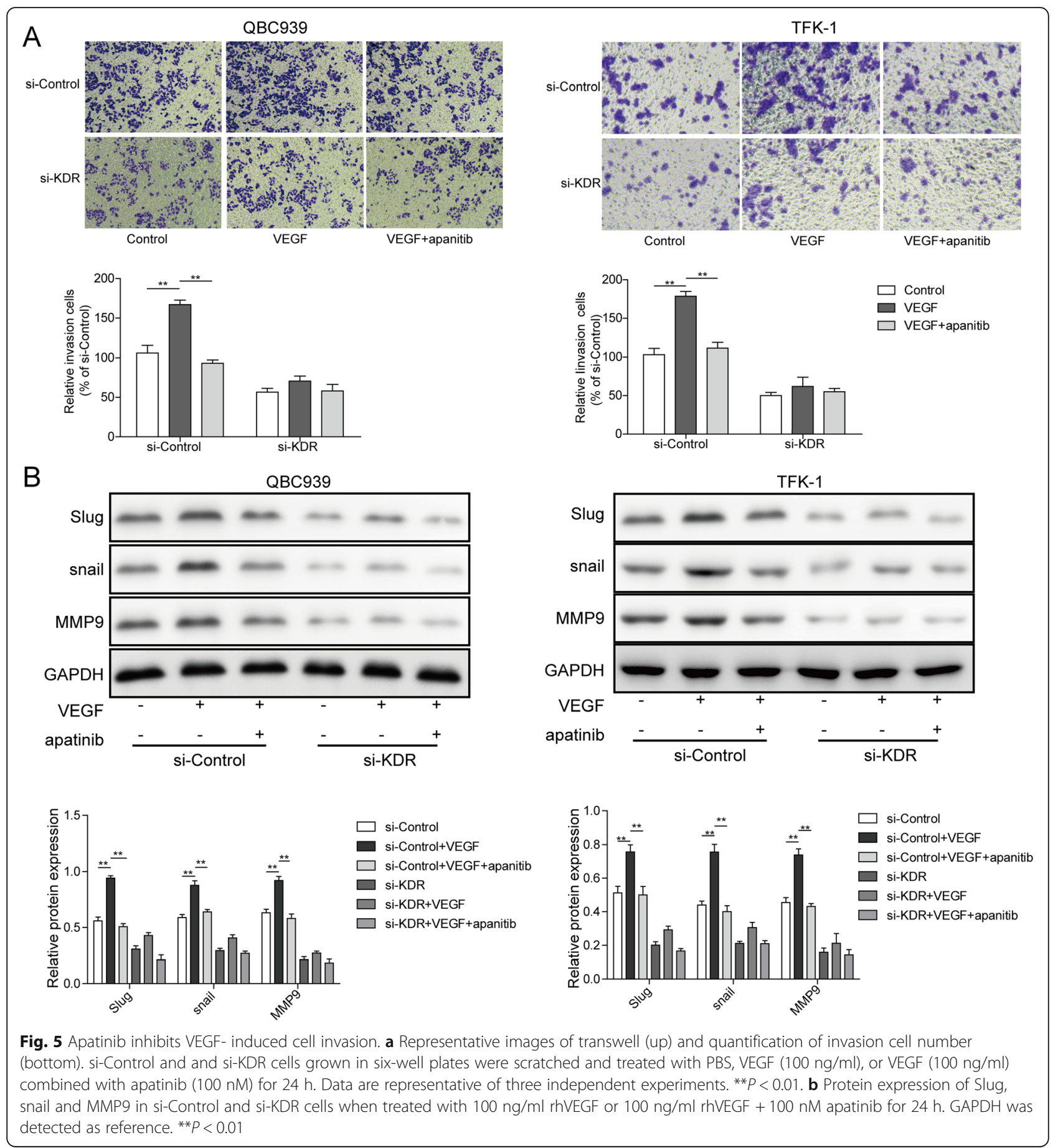

which was induced by VEGF, Besides, we also checked the PI3K/AKT pathway, which was identified as a VEGF related signaling pathway $[9,19,20,31]$. Same results were gained such like the detection of RAF/MEK/ERK1/2 pathway, which provided another molecular mechanism of apatinib acted on CCA cells. These results are supported by several studies that the anti-apoptosis effect of VEGF closely related to PI3K/AKT/mTOR signaling pathway [9, 19, 20, 31]. Previous studies has revealed that both VEGF/
MEK/ERK and PI3K/AKT pathways play key role in developing CCA $[9,24,25,30]$. Here, we found that apatinib could reverse the rhVEGF induced cell migration and invasion by blocking these two pathways. Combined with our data and references we have mentioned above, apatinib has an important role in CCA migration and invasion, and apatinib exerts excellent anti-tumor function in CCA cell lines. However, whether apatinib could perform the same antitumor function of CCA in vivo still needs to be 


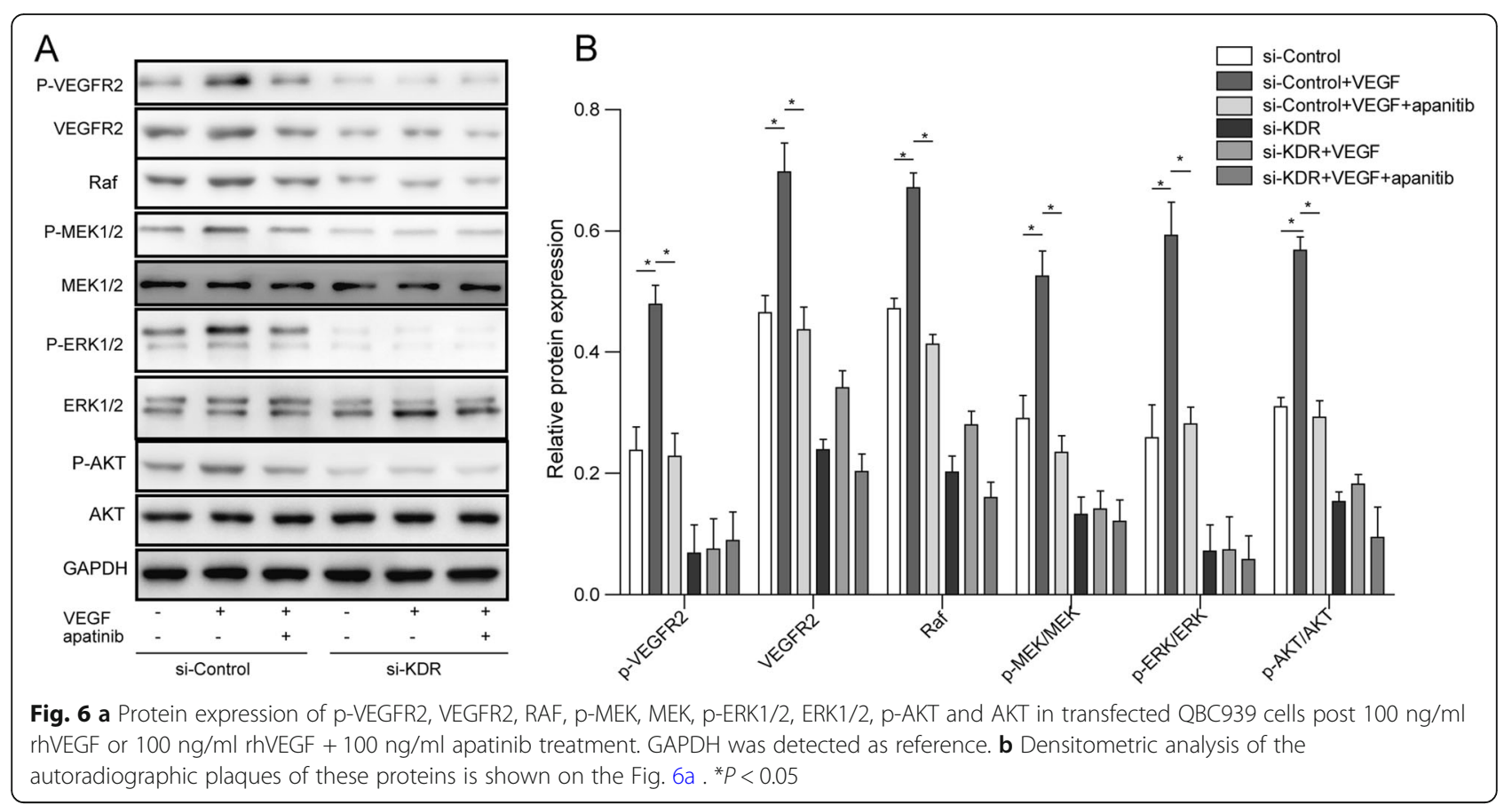

studied. Additionally, since angiogenesis of endothelial cells is an important factor in promoting tumor metastasis, and apatinib might play key role in angiogenesis via VEGFR2 as it expressed in endothelial cells. This would be worth to study in our future work.

\section{Conclusions}

In conclusion, our study demonstrates that apatinib inhibits VEGF-mediated cell migration and invasion of CCA cell lines, possibly by blocking VEGFR2-dependent RAF/ MEK/ERK and PI3K/AKT pathways. Our article shows the migration and invasion inhibition effect of apatinib acting directly on the CCA cell lines for the first time, hoping to attract more researchers' attention on deeper understanding and evaluating the potential clinical utility of apatinib.

\section{Abbreviations}

CCA: Cholangiocarcinoma; KDR: Kinase insert domain receptor, also known as VEGFR2; rhVEGF: Recombined human VEGF; siKDR: Small interference KDR; VEGF: Vascular endothelial growth factor; VEGFR2: VEGF receptor 2

\section{Acknowledgements}

This work was supported by the Joint Project of Natural Science Foundation of Hunan Province and Department of Science and Technology of Hunan Province and Commission of Health and Family Planning of Hunan Province [No.2018JJ6029].

\section{Availability of data and materials}

The data can be available from authors upon request.

\section{Authors' contributions}

HMP designed the study, prepared and edited the manuscript. HB performed experimental studies and acquired data. LGW analysed data and did literature research. ZSN designed the study and reviewed the manuscript. All authors have read and approved the manuscript.
Ethics approval and consent to participate

Not applicable.

\section{Consent for publication}

Not applicable.

\section{Competing interests}

The authors declare that there are no competing interests.

\section{Publisher's Note}

Springer Nature remains neutral with regard to jurisdictional claims in published maps and institutional affiliations.

\section{Author details}

'Department of Intervention, Hunan Cancer Hospital \& The Affiliated Cancer Hospital of Xiangya School of Medicine, Central SouthUniversity, No.283, Tongzipo Road, Changsha 410013, People's Republic of China. ${ }^{2}$ Infection Controlling Center, The Third Xiangya Hospital of Central South University, Tongzipo Road, Yuelu District, Changsha 410013, People's Republic of China.

Received: 7 December 2017 Accepted: 10 September 2018

Published online: 06 November 2018

\section{References}

1. Abdel-Razik A, ElMahdy Y, Hanafy EE, Elhelaly R, Elzehery R, Tawfik AM, Eldars W. Insulin-like growth Factor-1 and vascular endothelial growth factor in malignant and benign biliary obstructions. Am J Med Sci. 2016;351(3): 259-64.

2. Amo $Y$, Masuzawa M, Hamada $Y$, Katsuoka K. Serum concentrations of vascular endothelial growth factor-D in angiosarcoma patients. $\mathrm{Br} J$ Dermatol. 2004;150(1):160-1.

3. Berra E, Milanini J, Richard DE, Le GM, Viñals F, Gothié E, Roux D, Pagès G, Pouysségur J. Signaling angiogenesis via p42/p44 MAP kinase and hypoxia. Biochem Pharmacol. 2000:60(8):1171.

4. Callea F, Sergi C, Fabbretti G, Brisigotti M, Cozzutto C, Medicina D. Precancerous lesions of the biliary tree. J Surg Oncol. 2010;53(S3):131-3.

5. Chatterjee S, Heukamp LC, Siobal M, Schottle J, Wieczorek C, Peifer M, Frasca D, Koker M, Konig K, Meder L, Rauh D, Buettner R, Wolf J, Brekken RA, Neumaier B, Christofori G, Thomas RK, Ullrich RT. Tumor VEGF:VEGFR2 
autocrine feed-forward loop triggers angiogenesis in lung cancer. J Clin Invest. 2013;123(4):1732-40

6. Deoliveira ML, Cunningham SC, Cameron JL, Kamangar F, Winter JM, Lillemoe KD, Choti MA, Yeo CJ, Schulick RD. Cholangiocarcinoma: thirtyone-year experience with 564 patients at a single institution. Ann Surg. 2007;245(5):755-62.

7. Gaudio E, Barbaro B, Alvaro D, Glaser S, Francis H, Ueno Y, Meininger CJ, Franchitto A, Onori P, Marzioni M, Taffetani S, Fava G, Stoica G, Venter J, Reichenbach R, De Morrow S, Summers R, Alpini G. Vascular endothelial growth factor stimulates rat cholangiocyte proliferation via an autocrine mechanism. Gastroenterology. 2006;130(4):1270.

8. Eremina V, Quaggin SE. The role of VEGF-A in glomerular development and function. Curr Opin Nephrol Hypertens. 2004;13(1):9-15.

9. Ewald F, Norz D, Grottke A, Hofmann BT, Nashan B, Jucker M. Dual inhibition of PI3K-AKT-MTOR- and RAF-MEK-ERK-signaling is synergistic in cholangiocarcinoma and reverses acquired resistance to MEK-inhibitors. Investig New Drugs. 2014;32(6):1144-54

10. Ferrara N, Gerber HP, Lecouter J. The biology of VEGF and its receptors. Nat Med. 2003;9(6):669

11. Gupta K, Kshirsagar S, Li W, Gui L, Ramakrishnan S, Gupta P, Law PY, Hebbel RP. VEGF prevents apoptosis of human microvascular endothelial cells via opposing effects on MAPK/ERK and SAPK/JNK signaling. Exp Cell Res. 1999;247(2):495

12. Li YY, Li H, Lv P, Liu G, Li XR, Tian BN, Chen DJ. Prognostic value of cirrhosis for intrahepatic cholangiocarcinoma after surgical treatment. J Gastrointest Surg. 2011;15(4):608-13.

13. Lin C, Wang S, Xie W, Zheng R, Gan Y, Chang J. Apatinib inhibits cellular invasion and migration by fusion kinase KIF5B-RET via suppressing RET/Src signaling pathway. Oncotarget. 2016;7(37):59236-44.

14. Liu Y, Qiao Y, Hu C, Liu L, Zhou L, Liu B, Chen H, Jiang X. VEGFR2 inhibition by RNA interference affects cell proliferation, migration, invasion, and response to radiation in Calu-1 cells. Clinical \& translational oncology. 2016;18(2):212-9.

15. Lv L, Wei M, Lin P, Chen Z, Gong P, Quan Z, Tang Z. Integrated mRNA and IncRNA expression profiling for exploring metastatic biomarkers of human intrahepatic cholangiocarcinoma. Am J Cancer Res. 2017;7(3):688-99.

16. Ma FC, Yu Q, Zeng ZM, He RQ, Mo CH, Zhong JC, Ma J, Feng ZB, Chen G, $\mathrm{Hu} \mathrm{XH}$. Progression-free survival of up to 8 months of an advanced intrahepatic cholangiocarcinoma patient treated with apatinib: a case report. Onco Targets Ther. 2017:10:5237-42.

17. Meadows KN, Bryant P, Pumiglia K. Vascular endothelial growth factor induction of the angiogenic phenotype requires Ras activation. J Biol Chem. 2001;276(52):49289-98

18. Park BK, Paik YH, Park JY, Park KH, Bang S, Park SW, Chung JB, Park YN, Song SY. The clinicopathologic significance of the expression of vascular endothelial growth factor-C in intrahepatic cholangiocarcinoma. Am J Clin Oncol. 2006;29(2):138.

19. Peng H, Zhang Q, Li J, Zhang N, Hua Y, Xu L, Deng Y, Lai J, Peng Z, Peng B, Chen M, Peng S, Kuang M. Apatinib inhibits VEGF signaling and promotes apoptosis in intrahepatic cholangiocarcinoma. Oncotarget. 2016b;7(13): 17220-9.

20. Peng S, Zhang $Y$, Peng $H$, Ke Z, Xu L, Su T, Tsung A, Tohme S, Huang $H$, Zhang Q, Lencioni R, Zeng Z, Peng B, Chen M, Kuang M. Intracellular autocrine VEGF signaling promotes EBDC cell proliferation, which can be inhibited by Apatinib. Cancer Lett. 2016d:373(2):193-202.

21. Ramirez-Merino N, Aix SP, Cortes-Funes H. Chemotherapy for cholangiocarcinoma: an update. World J Gastrointest Oncol. 2013;5(7):171-6.

22. Rizvi S, Gores GJ. Pathogenesis, diagnosis, and management of cholangiocarcinoma. Gastroenterology. 2013;145(6):1215-29.

23. Senger DR, Galli SJ, Dvorak AM, Perruzzi CA, Harvey VS, Dvorak HF. Tumor cells secrete a vascular permeability factor that promotes accumulation of ascites fluid. Science. 1983;219(4587):983-5.

24. Shroff RT, Yarchoan M, O'Connor A, Gallagher D, Zahurak ML, Rosner G, Ohaji C, Sartorius-Mergenthaler S, Subbiah V, Zinner R, Azad NS. The oral VEGF receptor tyrosine kinase inhibitor pazopanib in combination with the MEK inhibitor trametinib in advanced cholangiocarcinoma. Br J Cancer. 2017;116(11):1402-7.

25. Simone V, Brunetti O, Lupo L, Testini M, Maiorano E, Simone M, Longo V, Rolfo C, Peeters M, Scarpa A, Azzariti A, Russo A, Ribatti D, Silvestris N. Targeting angiogenesis in biliary tract cancers: an open option. Int J Mol Sci. 2017;18(2).
26. Tang $D$, Nagano $H$, Yamamoto $H$, Wada $H$, Nakamura $M$, Kondo $M$, Ota $H$, Yoshioka S, Kato H, Damdinsuren B. Angiogenesis in cholangiocellular carcinoma: expression of vascular endothelial growth factor, angiopoietin-1/ 2, thrombospondin-1 and clinicopathological significance. Oncol Rep. 2006; 15(3):525-32.

27. Terman Bl, Dougher-Vermazen M, Carrion ME, Dimitrov D, Armellino DC, Gospodarowicz D, Bohlen P. Identification of the KDR tyrosine kinase as a receptor for vascular endothelial cell growth factor. Biochem Biophys Res Commun. 1992;187(3):1579-86.

28. Tian S, Quan H, Xie C, Guo H, Lu F, Xu Y, Li J, Lou L. YN968D1 is a novel and selective inhibitor of vascular endothelial growth factor receptor-2 tyrosine kinase with potent activity in vitro and in vivo. Cancer Sci. 2011;102(7):1374-80.

29. Tsuzuki T, Ogata Y, lida S, Nakanishi I, Takenaka Y, Yoshii H. Carcinoma of the bifurcation of the hepatic ducts. Arch Surg. 1983;118(10):1147.

30. Wiedmann MW, Mossner J. Molecular targeted therapy of biliary tract cancer-results of the first clinical studies. Curr Drug Targets. 2010;11(7):834-50.

31. Xu D, Ma Y, Zhao B, Li S, Zhang Y, Pan S, Wu Y, Wang J, Wang D, Pan H, Liu $\mathrm{L}$, Jiang $\mathrm{H}$. Thymoquinone induces G2/M arrest, inactivates PI3K/Akt and nuclear factor-kappaB pathways in human cholangiocarcinomas both in vitro and in vivo. Oncol Rep. 2014;31(5):2063-70.

32. Zhang L, Wang JN, Tang JM, Kong $X$, Yang JY, Zheng F, Guo LY, Huang YZ, Zhang $L$, Tian $L$. VEGF is essential for the growth and migration of human hepatocellular carcinoma cells. Mol Biol Rep. 2012;39(5):5085-93.

\section{Ready to submit your research? Choose BMC and benefit from:}

- fast, convenient online submission

- thorough peer review by experienced researchers in your field

- rapid publication on acceptance

- support for research data, including large and complex data types

- gold Open Access which fosters wider collaboration and increased citations

- maximum visibility for your research: over $100 \mathrm{M}$ website views per year

At BMC, research is always in progress.

Learn more biomedcentral.com/submissions 